\title{
PENGARUH PENDAPATAN RUMAH TANGGA TERHADAP KONSUMSI DAGING BROILER DI KELURAHAN KLEAK KECAMATAN MALALAYANG MANADO
}

\author{
Mexen A. Putong, J.K.J Kalangi*, M.T. Massie, T.F.D. Lumi
}

\section{Fakultas Peternakan Universitas Sam Ratulangi Manado, 95115}

\begin{abstract}
ABSTRAK
Penelitian ini bertujuan untuk mengetahui berapa besar jumlah konsumsi daging broiler di setiap rumah tangga berdasarkan tingkat pendapatan rumah tangga responden di kelurahan Kleak Kecamatan Malalayang Manado dan untuk mengetahui pengaruh tingkat pendapatan rumah tangga terhadap konsumsi daging broiler di kelurahan Kleak Kecamatan Malalayang Manado. Metode yang digunakan ialah metode survey lapangan pada satu kelurahan data yang diambil terdiri dari data primer dan sekunder. Data primer yaitu data yang berasal dari sumber asli atau responden yang diperoleh melalui wawancara dengan menggunakan daftar kuesioner. Kelurahan Kleak adalah salah satu Kelurahan yang ada di Kecamatan Malalayang Kota Manado. Dengan jumlah kepala keluarga 806 dan jumlah keseluruhan penduduk 2.705 jiwa. Berdasarkan variabel dan pengukurannya, maka dalam penelitian ini dilakukan beberapa asumsi - asumsi yang bermanfaat untuk membatasi satuan pengukuran variabel - variabelnya. Dari hasil penelitian ini dapat disimpulkan bahwa pendapatan berpengaruh positif terhadap konsumsi daging broiler pada rumah tangga di Kelurahan Kleak Kecamatan Malalayang Manado. Dengan formulasi Y $=19368,49+0,013 \mathrm{X}$. Artinya semakin bertambah pendapatan per 1 rupiah maka konsumsi naik sebesar 0,013 dengan asumsi variabel lainnya tetap (ceteris paribus).
\end{abstract}

Kata Kunci: Pendapatan, Konsumsi, Rumah tangga.

* Korespondensi (corresponding Author)

Email : jolandakalangi@unsrat.ac.id

\begin{abstract}
THE EFFECT OF HOUSEHOLD INCOME ON BROILER MEAT CONSUMPTION AT KLEAK URBAN VILLAGE OF MALALAYANG SUB DISTRICT MANADO. The study was done to determine the amount of broiler meat consumption in each household based on the level of household income at Kleak urban village of Malalayang sub district in Manado. The survey was used to get primary and secondary data. Primary data were taken from 30 samples of respondents obtained through interviews using the questionnaire. Kleak is one among urban village in Malalayang Sub District with the total of 806 households and consist of 2.705 population. Data Based on the variables and their measurements, the results of this study showed that income had the positive effect on broiler meat consumption of households on the Kleak urban village Malalayang Sub District in Manado following the formulation, $Y=19368.49+$ $0.013 \mathrm{X}$. This implied that as income increases per IDR 1 consumption increased by $0.013 \mathrm{~kg}$ assuming the other variables are fixed (ceteris paribus).
\end{abstract}

Keywords: Broiler meat consumption, household income.

\section{PENDAHULUAN}

Pembangunan

sub-sektor

peternakan merupakan bagian dari pembangunan sektor pertanian. Sub-sektor peternakan memiliki nilai strategis dalam memenuhi kebutuhan makanan yang terus 
meningkat seiring dengan bertambahnya jumlah penduduk dan peningkatan ratarata pendapatan masyarakat Indonesia.

Konsumsi daging di indonesia dari tahun ke tahun terjadi peningkatan dengan adanya pertambahan penduduk dan tuntutan perbaikan gizi masyarakat (Dewi dan Ari, 2014). Meningkatnya kesadaran masyarakat mengenai kebutuhan mengkonsumsi makanan yang memiliki nilai gizi yang cukup, juga ikut mempengaruhi peningkatan jumlah permintaan serta kebutuhan masyarakat akan bahan makanan yang memiliki nilai protein yang cukup tinggi, seperti daging, susu dan telur. Salah satu upaya meningkatkan konsumsi protein asal ternak adalah meningkatkan kontribusi produksi peternakan baik berupa daging, susu dan telur Badoa et al. (2016).

Dalam rangka mendukung perkembangan sektor peternakan, pemerintah telah menyusun berbagai langkah kebijakan, antara lain memacu pembangunan peternakan dengan meningkatkan perannya sebagai penghasil protein hewani yang bernilai tinggi melalui peningkatan produksi protein asal ternak. Produk hasil peternakan menyediakan gizi yang baik untuk memenuhi kebutuhan nutrisi bagi masyarakat luas. Pentingnya mengonsumsi pagan hewani dalam mencapai kebutuhan gizi konsumsi pangan hewani. Pangan hewani memiliki skor tertinggi setelah padi-padian sebagai sumber karbohidrat diantara beberapa komoditas pangan. Hal ini menunjukkan bahwa pangan hewani memiliki peranan strategis dalam pencapaian kebutuhan gizi konsumsi pangan yang baik. Daging telur, dan susu merupakan produk hasil ternak yang sering dikonsumsi masyarakat. Salah satu bahan makanan yang memberikan sumbangan yang sangat besar bagi kebutuhan terhadap protein hewani adalah daging ayam. Daging ayam sangat disukai oleh masyarakat karena daging ayam mudah dimasak dan diolah. Selain itu, daging ayam juga memiliki rasa yang enak dan dapat diterima semua golongan masyarakat serta harga yang relative lebih murah dibandingkan daging lainnya (Rahardi dan Hartono, 2003).

\section{METODE PENELITIAN}

Penelitan ini telah dilaksanakan di Kota Manado Kecamatan Malalayang Kelurahan Kleak pada tanggal 1 November sampai 30 November 2018. Dengan jumlah rumah tangga yang ada di lokasi penelitian sebesar 806 rumah tangga dan jumlah keseluruhan penduduk sebesar 2.705. Metode yang digunakan ialah metode survey lapangan pada satu kelurahan. Data yang diambil terdiri dari data primer dan sekunder. Data primer yaitu data yang berasal dari sumber asli 
atau responden yang diperoleh melalui wawancara dengan menggunakan daftar kuesioner. Data sekunder yaitu data yang diperoleh melalui Kantor Kelurahan Kleak Kecamatan Malalayang Manado. Penentuan sampel Kelurahan Kleak dilakukan secara purposive sampling yaitu Kelurahan yang memiliki penduduk yang paling banyak. Responden ditentukan secara simple random sampling ( Arikunto 2002) yaitu sampel secara acak sederhana. Penelitian ini menggunakan sampel sabanyak 30 rumah tangga yang dipilih secara random.

\section{HASIL DAN PEMBAHASAN}

\section{Karakteristik Responden}

Umur responden merupakan salah satu karakteristik yang mempengaruhi tingkat konsumsi. Umur juga merupakan salah satu faktor pendukung untuk meningkatkan produktivitas kerja sehingga berpengaruh terhadap pembangunan suatu wilayah, baik dari aspek ekonomi, sosial dan budaya. Hasil penelitian terhadap 30 responden yang mengkonsumsi daging broiler di Kelurahan Kleak Kecamatan Malalayang menunjukkan bahwa umur responden yang mengkonsumsi daging broiler bervariasi antara 1 tahun sampai 75 tahun. Jumlah responden terbanyak berada pada kelompok umur 1-30 tahun yaitu sebesar $66 \%$ dan yang responden paling rendah pada kelompok umur 51-75 tahun sebesar 14\%. Hasil penelitian menunjukkan bahwa umur adalah salah satu pengaruh terhadap jumlah konsumsi daging broiler. Hal ini ditunjang oleh hasil penelitian (Ambat, 2011) dan Aisyah (2011) bahwa responden pada umur produktif diindikasikan lebih mudah merespon informasi yang diperoleh diantaranya informasi tentang pentingnya konsumsi protein hewani asal ternak yang Penting untuk kesehatan tubuh manusia. Makanan sehari-hari akan sangat menentukan kualitas kesehatan seseorang. Oleh karena itu sudah seharusnya setiap individu memperhatikan makanan yang dimakan setiap hari. Kebutuhan makanan juga bukan hanya untuk menumbuhkan badan secara fisik tetapi juga mempengaruhi kecerdasan serta kondisi psikologis seseorang. Tetapi umur juga mempunyai batas terhadap tingkat konsumsi daging dalam hal ini daging broiler yang dapat menyebabkan penyakit yang membahayakan kesehatan tubuh manusia jika dikosumsi secara berlebihan oleh masyarakat yang sudah mencapai umur usia lanjut. Maka dari itu masyarakat diharapkan memiliki pengetahuan akan kecukupan gizi yang telah dianjurkan untuk di konsumsi sehari-hari sesuai umur. Tingkat umur yang berada pada lokasi penelitian di Kelurahan Kleak Kecamatan Malalayang dapat dilihat pada Tabel 1. 
Tabel 1. Umur Responden

\begin{tabular}{cccc}
\hline No & $\begin{array}{c}\text { Kelompok Umur } \\
\text { (Tahun) }\end{array}$ & $\begin{array}{c}\text { Jumlah Responden } \\
\text { (Orang) }\end{array}$ & Pesentase (\%) \\
\hline 1 & $1-30$ & 20 & 66 \\
2 & $31-50$ & 6 & 20 \\
3 & $51-75$ & 4 & 14 \\
\hline & Jumlah & 30 & 100 \\
\hline
\end{tabular}

Tabel 2. Tingkat Pendidikan Responden

\begin{tabular}{cccc}
\hline No & Tingkat Pendidikan & $\begin{array}{c}\text { Jumlah Responden } \\
\text { (Orang) }\end{array}$ & Persentase (\%) \\
\hline 1 & S1-S2 & 22 & 74 \\
2 & SMA & 8 & 26 \\
\hline & Jumlah & 30 & 100 \\
\hline
\end{tabular}

Pendidikan seseorang akan makanan dari tampilan yang bagus dan mempengaruhi perilaku dalam membeli rasa yang enak saja namun lebih suatu produk, karena semakin tinggi mempertimbangkan nutrisi dan kandungan tingkat pendidikannya semakin selektif dalam memilih suatu produk yang gizi.

Pekerjaan merupakan sumber dibutuhkannya jumlah responden berdasarkan tingkat pendidikan Yunus (2007).

Berdasarkan Tabel 2, diketahui bahwa 74 persen responden berpendidikan sarjana dan pasca sarjana sedangkan tingkat SMA delapan responden dengan tingkat presentase 26 persen $\mathrm{Hal}$ ini menunjukkan bahwa semakin tinggi tingkat pendidikan seseorang maka semakin tinggi juga pengetahuan akan manfaat kesehatan, tidak hanya melihat 
Tabel 3. Jenis Pekerjaan Responden

\begin{tabular}{cccc}
\hline No & Jenis Pekerjaan & $\begin{array}{c}\text { Jumlah Responden } \\
\text { (Orang) }\end{array}$ & Persentase (\%) \\
\hline 1 & Swasta & 20 & 66 \\
2 & PNS & 5 & 16 \\
3 & Pensiunan & 3 & 10 \\
4 & Wirausaha & 1 & 4 \\
5 & Tukang & 1 & 4 \\
\hline & Jumlah & 30 & 100 \\
\hline
\end{tabular}

Berdasarkan jenis pekerjaan responden menunjukkan yang swasta dengan jumlah responden 20 dengan presentase 66\%, PNS 5 Responden dengan persentase $16 \%$, Pensiunan 3 responden dengan persentase $10 \%$, wirausaha 1 responden dengan presentase 4 persen, tukang 1 responden dengan persentase 4 persen. Hal ini menunjukkan usia produktif di Kelurahan Kleak cukup banyak dalam penelitian ini, mereka bekerja untuk memenuhi kebutuhan sehari-hari rumah tangga mereka. Selain itu pekerjaan sangat berpengaruh terhadap tingkat pendapatan responden. Ketika tidak bekerja maka sudah pasti responden tidak memiliki pendapatan.

Pendapatan responden di Kelurahan Kleak Kecamatan Malalayang dalam penelitian ini menunjukkan besarnya pendapatan rumah tangga menentukan besarnya konsumsi produk ternak Bahari et al. (2012). Hasil dari penelitian menunjukkan pendapatan responden bervariasi yaitu dari Rp.2.500.000/bulan, sampai Rp. 8.000.000/bulan. Jumlah responden terbanyak yaitu responden yang memiliki pendapatan antara Rp. 2.500.000,- sampai dengan Rp. 3.000.000,- perbulan dengan presentase 66 persen. Melihat perbedaan pendapatan yang dimiliki oleh responden di Kelurahan Kleak Kecamatan Malalayang tentunya akan berdampak pada jumlah pembelian daging broiler setiap bulannya. Hasil penelitian Osak et al. (2014) dalam penelitiannya juga mendapatkan hasil yang sama bahwa pendapatan responden memiliki pengaruh terhadap konsumsi daging. Jumlah pendapatan responden dapat dilihat pada Tabel 4. 
Tabel 4. Jumlah Pendapatan Responden

\begin{tabular}{cccc}
\hline No & Pendapatan (Rp) & $\begin{array}{c}\text { Responden } \\
\text { (Orang) }\end{array}$ & Presentase (\%) \\
\hline 1 & $2.500 .000-3.000 .000$ & 20 & 66 \\
2 & $3.100 .000-6.000 .000$ & 6 & 20 \\
3 & $6.000 .000-8.000 .000$ & 4 & 14 \\
\hline \multicolumn{2}{c}{ Jumlah } & 30 & 100 \\
\hline
\end{tabular}

\section{Pengaruh Pendapatan Rumah Tangga} Terhadap Konsumsi Daging Broiler

Hasil analisis pengaruh pendapatan rumah tangga terhadap konsumsi daging broiler di Kelurahan Kleak Kecamatan Malalayang dinyatakan dalam hasil estimasi analisis dengan formulasinya sebagai berikut:

$$
Y=19368,49+0,013 X .
$$

Hal ini menunjukkan bahwa semakin bertambah pendapatan rumah tangga maka konsumsi akan meningkat. Secara statistik hasil estimasi menunjukkan semakin bertambah pendapatan per 1 rupiah maka konsumsi rumah tangga akan naik sebesar $0,013 \mathrm{~kg}$ daging broiler dengan asumsi variabel lainnya tetap (ceteris paribus). Nilai thitung yang diperoleh sebesar 12,7203 menunjukkan secara signifikan pendapatan rumah tangga berpengaruh terhadap konsumsi daging broiler $(\mathrm{P}<0,01)$ Artinya apabila pendapatan rumah tangga meningkat maka akan cendrung terjadinya perubahan terhadap konsumsi daging broiler di Kelurahan Kleak Kecamatan
Malalayang. Hasil ini ditunjang oleh penelitian Elvis et al., (2014) bahwa meningkatnya pendapatan meningkatkan konsumsi rumah tangga terhadap daging dan telur di Kecamatan Tareran. Hal ini juga sejalan dengan teori ekonomi bahwa semakin tinggi pendapatan maka konsumsi suatu barang cenderung akan meningkat Taspin et al. (2014).

\section{KESIMPULAN}

Dari hasil penelitian ini dapat disimpulkan bahwa pendapatan rumah tangga berpengaruh terhadap konsumsi daging broiler.

\section{DAFTAR PUSTAKA}

Arikunto, S. 2002. Prosedur Penelitian Suatu Pendekatan Praktek. Edisi Revisi V. Bina Aksara. Yogyakarta.

Ambat, A.G. 2011. Analisis konsumsi daging di Kecamatan Tikala Kota Manado. Skripsi. Fakultas Peternakan Unsrat. Manado

Aisyah, 2011. Faktor-faktor yang mempengaruhi preferensi 
konsumen. Jurnal Pendidikan Ekonomi Dan Koperasi. 6(1):168188.

Badoa, V.I, A.H.S., Salendu., F.H. Elly dan P.O.V. Waleleng. 2016. Pengaruh pendapatan terhadap konsumsi daging dan telur di Kecamatan Siau Barat Kabupaten Kepulauan Siau Tagulandang Biaro. Jurnal Zootek 36(1):61-68.

Bahari., H. Nufil., dan B. A. Nugroho. Analisis kontrak farming usaha ayam broiler. Jurnal Agro Ekonomi 30(2):109-127

Dewi W dan D. Ari, 2014. Variasi Resep Praktis Untuk Menu Sehari Hari Masakan Ayam. F Media.

Elvis, .F.W., B. Rorimpandey, G.D. Lenzu, E.K.M. Endoh. 2014. Analisis pengaruh pendapatan rumah tangga terhadap konsumsi daging dan telur di Desa Suluun Kecamatan Tareran Kabupaten Minahasa Selatan. Jurnal Zootek 34(1):37-47

Ghozali I. 2012. Aplikasi Analisis Pengaruh Multivariate Dengan Program IBM SPSS 20. Semarang: Badan penerbit Universitas Diponegoro.

Keintjem, R., F.S. Oley, G.D. Lenzun, J. Pandey. 2016. Pengaruh pendapatan terhadap konsumsi daging babi di Kecamatan Wanea Kelurahan Ranotana Weru. Jurnal Zootek 36(1):139-146

Osak, R.A.F., V.V.J. Panelewen, J. Pandey dan I.D.R. Lumenta. 2014. Pengaruh pendapatan rumah tangga terhadap konsumsi daging (sapi, babi dan ayam) di Desa Sea
1 Kecamatan Pineleng. Jurnal Zootek 34(2):10-17

Rahardi. F dan R. Hartono.. 2003. Agribisnis Peternakan. Penerbit Penebar Swadaya, Depok.

Yunus, . 2007. Analisis usaha peternakan ayam broiler studi kasus pada peternakan ayam broiler di Kelurahan Borongloe, Kecamatan Bontomaram, Kabupaten Gowa, Jurnal Agrisistim (1)3:1858-1865.

Taspin, G., \& Hepsag. A. 2014. Analysis of house hold consumption expen ditures. European Scientific Journal 10(16):1-12

Zentiko D.B., M. Handayani, I.S Santoso. 2014. Analisis break event point usaha peternakan ayam broiler Di Kecamatan Limbangan Kabupaten Kendal. Animal Agriculture Journal $4(1): 15-21$ 
